\title{
ON THE LARVAL DEVELOPMENT OF ELMINIUS MODESTUS DARWIN
}

\author{
By E. W. Knight-Jones and G. Duncan Waugh \\ Ministry of Agriculture and Fisheries, Burnham-on-Crouch, Essex
}

(Text-figs. I-6)

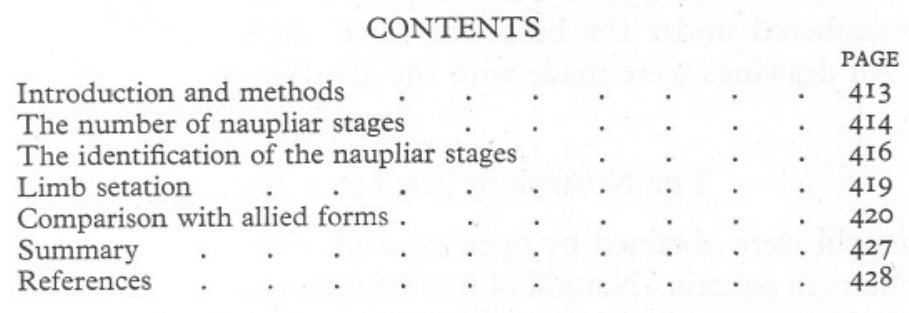

\section{INTRODUCTION AND MeTHODS}

Since its introduction to this country (see Bishop, 1947; Crisp \& Chipperfield, 1948) the barnacle Elminius modestus Darwin has become numerous on Essex oyster beds. Owing to its remarkably long season of settlement and great fecundity it competes with young oyster spat for space and food more keenly than any other sessile form (Knight-Jones, 1948). It is also a dominant fouling organism of coastal craft in Essex. Workers investigating ships' fouling and oyster problems may therefore need to identify its larval stages in the plankton. These stages have not hitherto been described.

Routine plankton sampling to record the abundance and growth of oyster larvae has been carried out in the Rivers Crouch and Roach during the summers of 1947 and 1948 . The standard sample used was obtained by filtering 1001 . of water, drawn from a depth of $2 \mathrm{~m}$. by a $\mathrm{I} \frac{1}{2}$ in. centrifugal pump. In I 948 cirripede nauplii were abundant in these samples throughout June and July. There were often several hundred per 1001 . Bassindale (1936) recorded that nauplii which were abundant in the Plymouth plankton during the late summer were Chthamalus stellatus and Balanus perforatus. In the Burnham-on-Crouch district, however, these two species appear to be absent. We have observed only four species of barnacles, B. balanoides, B. crenatus, B. improvisus and Elminius modestus. In 1948 the main settlement of both Balanus balanoides and B.crenatus occurred in April and neither species was observed to settle after 5 June. Settlement of Elminius modestus and Balanus improvisus occurred with varying intensity from May to September, and the great majority of barnacles settling during this period were Elminius. Evidently the majority of the larvae which were so numerous in the plankton during the summer were Elminius, so the 
routine I00 1 . samples provided ample material for the present study. It was necessary only to distinguish larvae of Elminius from those of Balanus improvisus.

This did not prove difficult (see pp. 424-6) and of over 300 nauplii obtained from June samples and examined, no more than eighteen proved to be B. improvisus. All these nauplii, together with some young larvae obtained in the laboratory from adult Elminius, were measured by means of an eyepiece micrometer. The number of naupliar stages in the development was deduced from their size distribution. The limb setation was then studied by the method advocated by Bassindale (1936). For this purpose several nauplii of each stage were dismembered under the binocular microscope by means of fine glass needles. All drawings were made with the aid of a camera lucida.

\section{The Number of Naupliar Stages}

Stage I nauplii were obtained by opening adult Elminius during June and by keeping others in aquaria. Nauplii of this stage were liberated by adults which had been living undisturbed for several days in a tank, the water of which was continually stirred. It is probable, therefore, that larvae are liberated at this stage under natural conditions. The first moult invariably occurred within $24 \mathrm{hr}$., however, and doubtless it is for this reason that very few Stage I nauplii were observed in the plankton. All batches kept in aquaria completed the first moult successfully, and Stage II nauplii were thus obtained. These and subsequent stages were also obtained from the plankton.

At the beginning of the work all cirripede nauplii which were seen in a selected plankton sample were measured. The measurements made included total length, greatest breadth and, in larvae in which the carapace fold had appeared, the length of the carapace. All measurements were taken to 0.01 of a millimetre. As work progressed it became possible to identify the larvae of Balanus improvisus and to judge which of those already measured belonged to this species. The data relating to these are not included here.

Presumably because of a high death-rate there were always far more younger larvae than older larvae in the samples. After measuring about 150 Elminius larvae it was clear that a greater proportion of early stages had been obtained and from then on only medium-and larger-sized nauplii were measured, except that occasional small specimens were measured to check that there was no appreciable difference in size between those liberated during the earlier and later parts of the season.

On examining the data it was decided that greatest breadth was the most useful measurement for identifying the various naupliar stages, since total length was affected by the degree of flexure of the abdomen, which varied considerably in different individuals, whilst carapace length could not be determined in early stages. The numbers of larvae which fell into each milli- 
metre size group are given in Table I. These figures are shown graphically in Fig. I. As already indicated, the larvae measured did not constitute a single random sample. Larvae measuring $0.14 \mathrm{~mm}$. or less were obtained only from batches liberated in aquaria. A few of those measuring $0.15-0.17 \mathrm{~mm}$. were obtained in the same way. The plankton samples from which the remainder were obtained were taken on several different dates during June and July, and

\section{TABLE I}

\begin{tabular}{|c|c|c|c|c|c|c|c|}
\hline $\begin{array}{l}\text { Greatest } \\
\text { breadth } \\
\text { (mm.) }\end{array}$ & $\begin{array}{l}\text { No. of } \\
\text { larvae }\end{array}$ & $\begin{array}{l}\text { Greatest } \\
\text { breadth } \\
\text { (mm.) }\end{array}$ & $\begin{array}{l}\text { No. of } \\
\text { larvae }\end{array}$ & $\begin{array}{l}\text { Greatest } \\
\text { breadth } \\
\text { (mm.) }\end{array}$ & $\begin{array}{l}\text { No. of } \\
\text { larvae }\end{array}$ & $\begin{array}{l}\text { Greatest } \\
\text { breadth } \\
\text { (mm.) }\end{array}$ & $\begin{array}{l}\text { No. of } \\
\text { larvae }\end{array}$ \\
\hline O.II & 2 & O.I9 & 23 & 0.27 & 5 & 0.35 & 9 \\
\hline 0.12 & I I & 0.20 & IO & 0.28 & IO & 0.36 & I3 \\
\hline O.I3 & IO & $0.2 \mathrm{I}$ & 0 & 0.29 & 9 & 0.37 & 3 \\
\hline 0.14 & 2 & 0.22 & 5 & 0.30 & IO & 0.38 & 3 \\
\hline 0.15 & 4 & 0.23 & 9 & 0.31 & 12 & 0.39 & 2 \\
\hline 0.16 & 25 & 0.24 & 27 & 0.32 & 0 & 0.40 & 2 \\
\hline 0.17 & IO & 0.25 & 7 & 0.33 & 3 & $0.4 \mathrm{I}$ & I \\
\hline 0.18 & 8 & 0.26 & 2 & 0.34 & 8 & & \\
\hline
\end{tabular}

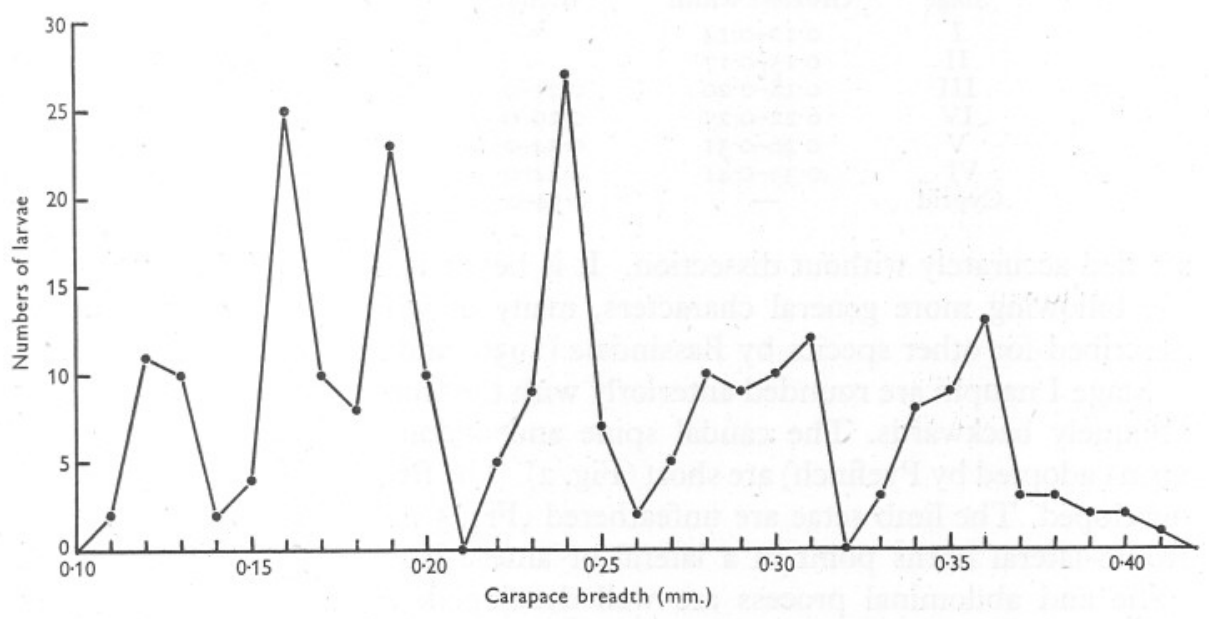

Fig. I. The size distribution, in O.I mm. groups, of all Elminius nauplii measured (245). The larvae did not constitute a single random sample, but such general selection as was exercised in obtaining them cannot account for the presence on this graph of six distinct peaks. These indicate that there are six naupliar stages in the development. This was corroborated by morphological study. The naupliar stage to which each size group belonged can be seen from Table II. In respect of this measurement (carapace breadth) no overlapping in size between successive stages was observed.

often only the larger larvae seen in a sample were measured. This selection was exercised only in a general way, to ensure that all sizes of larvae were adequately represented in the sample. Such general selection cannot account for the presence on this graph of six distinct peaks. These indicate that there are six naupliar stages in the development and that the later stages are much more 
variable in size than the earlier stages. The graphic evidence for six naupliar stages is corroborated by the determination of six distinct setation formulae (Table III, p. 420).

\section{The Identification of the Naupliar Stages}

The size limits observed for each stage are given in Table II. The measurements of carapace length included the length of the carapace spines, which varied rather widely between 0.015 and $0.045 \mathrm{~mm}$., but was usually 0.02 or $0.03 \mathrm{~mm}$. The measurements of total length showed much overlapping between successive stages, since the degree of flexure varied and was sometimes extreme, but other measurements afforded a fairly reliable means of identifying the stages. The limb setation of each stage is also characteristic, but this cannot be

Table II. Measurements of Larval Stages of Elminius modestus IN MM.

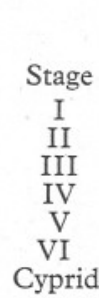

$\begin{array}{cc}\text { Greatest width } & \text { Length } \\ 0.1 \text { I }-0.14 & - \\ 0.15-0.17 & - \\ 0.18-0.20 & 0.2 \text { I }-0.25 \\ 0.22-0.25 & 0.29-0.35 \\ 0.26-0.31 & 0.34-0.44 \\ 0.33-0.4 I & 0.42-0.55 \\ - & 0.54-0.56\end{array}$

Full length
$0.24-0.26$
$0.36-0.43$
$0.35-0.43$
$0.39-0.50$
$0.45-0.57$
$0.48-0.71$
-

studied accurately without dissection. It is better to rely for identification on the following more general characters, many of which are similar to those described for other species by Bassindale (I936) and Pyefinch (I948).

Stage I nauplii are rounded anteriorly with the fronto-lateral horns pointing obliquely backwards. The caudal spine and abdominal process (to use the terms adopted by Pyefinch) are short (Fig. 2). The frontal filaments are not yet developed. The limb setae are unfeathered (Fig. 5). In subsequent stages the fronto-lateral horns point in a lateral or antero-lateral direction, the caudal spine and abdominal process are well developed, the frontal filaments are obvious and many of the limb setae are feathered.

Stage II nauplii are characteristically slender with a particularly long caudal spine and a shorter, narrow abdominal process. The prongs of the forked abdominal process are proportionately longer than in the other stages. There is no sign of a posterior edge to the carapace.

Stage III nauplii are of the same total length as those of Stage II but are of stouter build. The posterior edge of the carapace is well defined and bears a carapace spine on each side of the mid-dorsal line. There is no projecting carapace fold, however, so the carapace spines are closely applied to the body and often difficult to distinguish at this stage. The abdominal process is slightly swollen at the base and is about the same length as the caudal spine. In both 


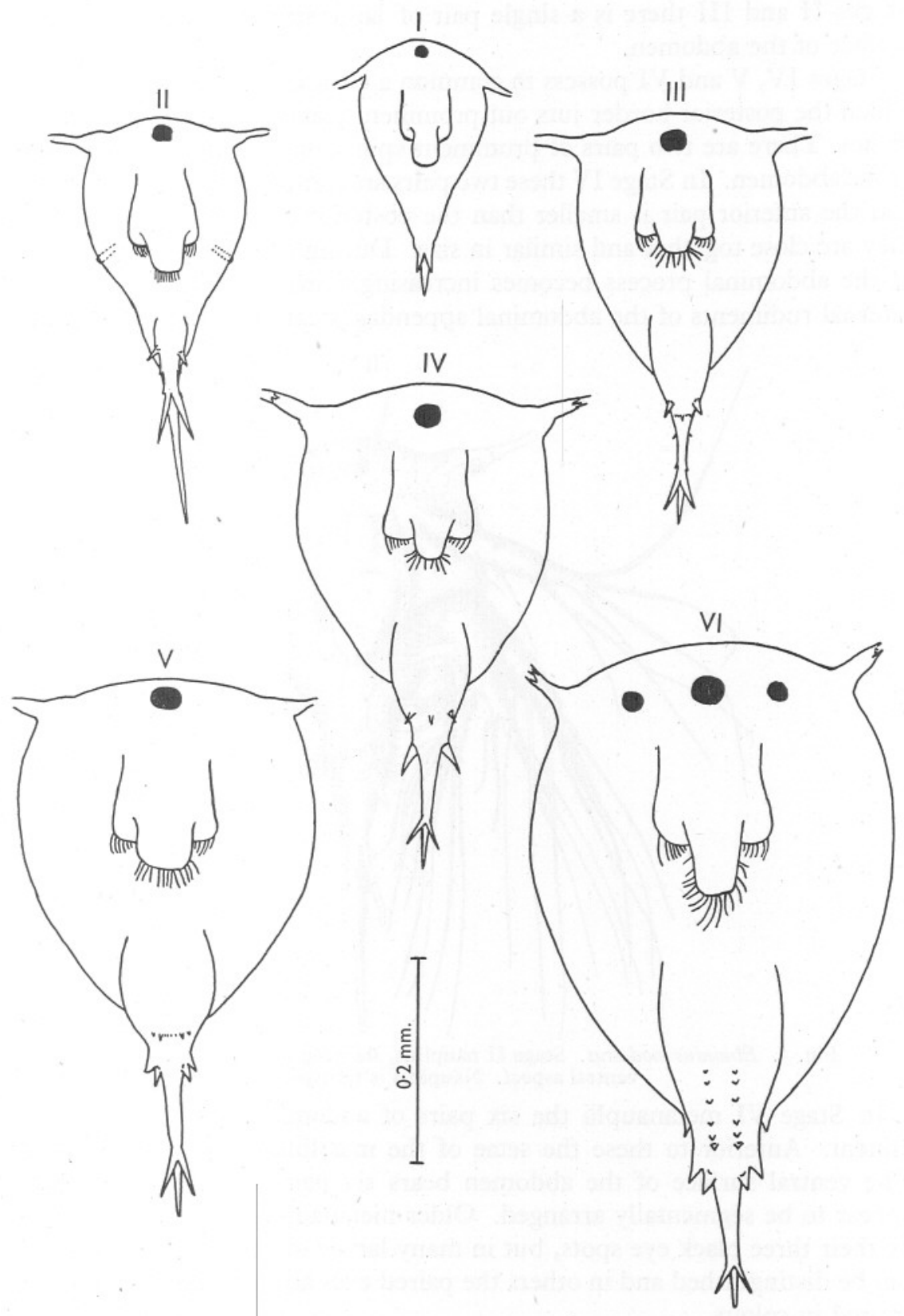

Fig. 2. Elminius modestus. Outline drawings of the six naupliar stages, showing the labrum, all to same scale. 
Stages II and III there is a single pair of large spines on the latero-ventral surface of the abdomen.

Stages IV, V and VI possess in common a rounded shape and a carapace of which the posterior border juts out prominently and bears a pair of carapace spines. There are two pairs of prominent spines on the latero-ventral surface of the abdomen. In Stage IV these two pairs are comparatively widely separated and the anterior pair is smaller than the posterior pair. In Stages V and VI they are close together and similar in size. During these three stages the base of the abdominal process becomes increasingly swollen, and in Stage V the internal rudiments of the abdominal appendages can be distinguished.

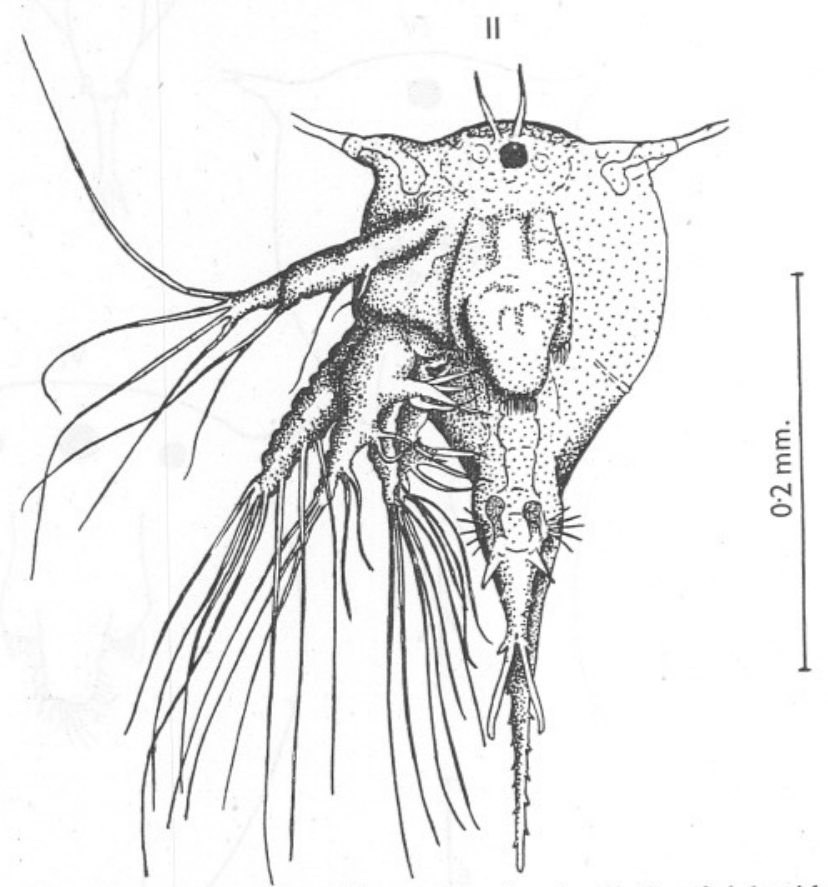

Fig. 3. Elminius modestus. Stage II nauplius, showing limbs of right side only, ventral aspect. Nauplius is transparent.

In Stage VI metanauplii the six pairs of abdominal appendages are prominent. Anterior to these the setae of the maxillulae can be distinguished. The ventral surface of the abdomen bears six pairs of small spines, which appear to be segmentally arranged. Older metanauplii are readily recognized by their three black eye spots, but in many larvae of this stage no paired eyes can be distinguished and in others the paired eyes are not fully pigmented and are red in colour.

Fig. 2 gives outline drawings of typical specimens of each stage all drawn to the same scale. Fig. 3 shows a Stage II nauplius in greater detail. Fig. 4 is a side view of a Stage VI nauplius and a cyprid. 

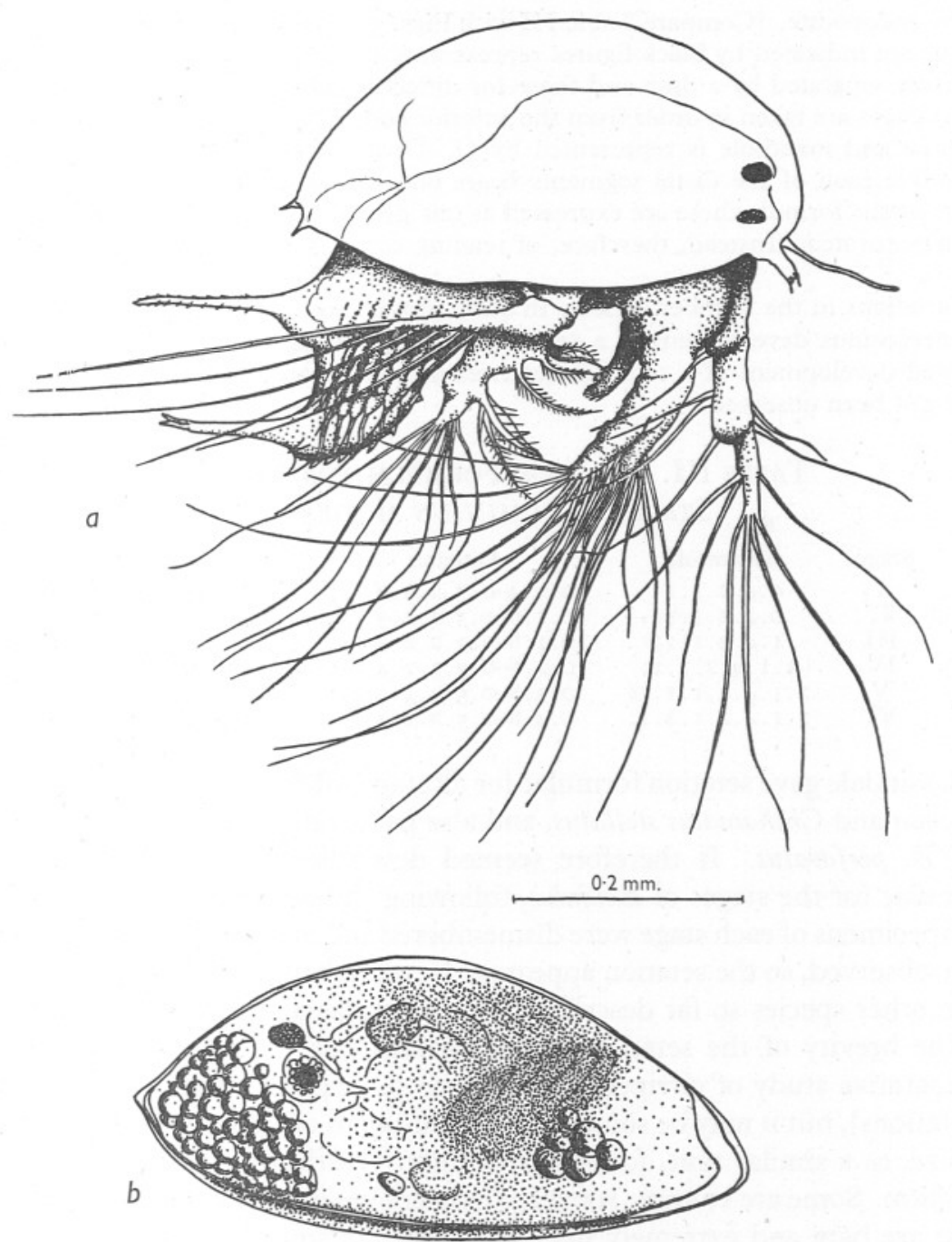

Fig. 4. Elminius modestus. $a$, Stage VI nauplius, right side; $b$, cyprid larva, left side.

\section{Limb Setation}

Bassindale (I936) wrote as follows:

In order to facilitate a comparison of barnacle nauplii a setation formula has been elaborated. The setae on the appendages of cirripede nauplii occur in groups along the dorsal and ventral sides of the appendages. Each group has been represented by a figure giving the actual number of setae present. The formula is obtained by arranging these numbers in order, reading from the base of each appendage along the dorsal edge of the exopodite, down its ventral edge, and then up the dorsal and down the ventral edges 
of the endopodite. [Compare Table III with Figs. 5 and 6.] The setae at the tip of each ramus are indicated by black figures representing the group; the formulae for the two rami are separated by a dash and those for different appendages by a semicolon. The appendages are taken in order from the anterior end. The gnathobase occurring on the antenna and mandible is represented by G. On the exopodites of the antenna and mandible each of the distal segments bears one strong swimming-seta. In order to contract the formula these are expressed as one group, the terminal seta or setae alone being separated. Instead, therefore, of reading O.I.I.I.I.I.I.I. the formula reads o.r.6.

Variations in the number of setae in some groups are found. This is usually due to the precocious development of a seta normally appearing at the next stage or to the delayed development of a seta. Differences of more than one seta in any one group have not been observed.

\section{Table III. Setation Formulae for the LaRval StAGES OF ELMINIUS MODESTUS}

$\begin{array}{cc}\text { Stage } & \text { Antennule } \\ \text { I } & 0.4 \cdot 2 . I . I ; \\ \text { II } & 0.4 \cdot 2 . \mathrm{I} . \mathrm{I} ; \\ \text { III } & \text { I.4.2.I.I; } \\ \text { IV } & \text { I.I.4.2.I.I; } \\ \text { V } & 2 . \mathrm{I} \cdot 4 \cdot 2 . \mathrm{I} . \mathrm{I} . \mathrm{I} ; \\ \text { VI } & 2 . \mathrm{I} \cdot 4 \cdot 2 . \mathrm{I} \cdot 2 . \mathrm{I} ;\end{array}$

Antenna
$0.1 .4-0.3 \cdot 2 \cdot 2 \cdot 2 \cdot G$
$0.1 .6-0.3 \cdot 2 \cdot 2 \cdot 3 \cdot G$
$0.1 .6-0.3 \cdot 2 \cdot 2 \cdot 4 \cdot G$
$0.2 \cdot 7-0.5 \cdot 3 \cdot 2 \cdot 4 \cdot G$
$0.3 \cdot 8-0.5 \cdot 3 \cdot 2 \cdot 4 \cdot G$
$0.4 \cdot 8-0.5 \cdot 3 \cdot 2 \cdot 4 \cdot G$

\section{Mandible}

$0.1 \cdot 3-0.3 \cdot 2 \cdot 2 \cdot 2 . \mathrm{G}$

$0.1 \cdot 3-0 \cdot 3 \cdot 2 \cdot 3 \cdot 2 \cdot G$

$0.1 \cdot 4-0.3 \cdot 3 \cdot 3 \cdot 3 \cdot G$

$0 . \mathrm{I} \cdot 4-0.4 \cdot 3 \cdot 3 \cdot 3 \cdot \mathrm{G}$

$0 . \mathrm{I} \cdot 5-0.4 \cdot 4 \cdot 4 \cdot 3 \cdot \mathrm{G}$

$0 . x \cdot 5-0.4 \cdot 4 \cdot 4 \cdot 3 . G$

Bassindale gave setation formulae for all stages of Balanus balanoides, Verruca stroemia and Chthamalus stellatus, and also gave some data for Balanus crenatus and $B$. perforatus. It therefore seemed desirable to work out the setation formulae for the stages of Elminius, following the same method. From five to ten specimens of each stage were dismembered and examined. No discrepancies were observed, so the setation appears to be remarkably constant for each stage, as in other species so far described. The formulae are given in Table III.

The brevity of the setation formula makes it a useful instrument for the comparative study of cirripede nauplii (see p. 424 for a brief discussion of its limitations), but it may be somewhat misleading to describe each seta, whatever its size, as a similar unit, for the setae differ greatly from one another in size and form. Some are stumpy, some are feathery bearing numerous setules, whilst some are bare and extremely fine, and some are small. In order to ascertain the setation formulae with certainty it proved necessary to draw each limb in detail. In Figs. 5 and 6 these drawings are reproduced, all to the same scale.

\section{Comparison with Allied Forms}

Bassindale (I936) described the naupliar stages of Balanus balanoides, Chthamalus stellatus and Verruca stroemia, compared them with those of Balanus perforatus as described by Groom (I894) and gave data for several other species. Pyefinch (I948) compared larvae of B. balanoides, B. crenatus and Verruca stroemia, with special reference to characters which can be recognized at a glance under 

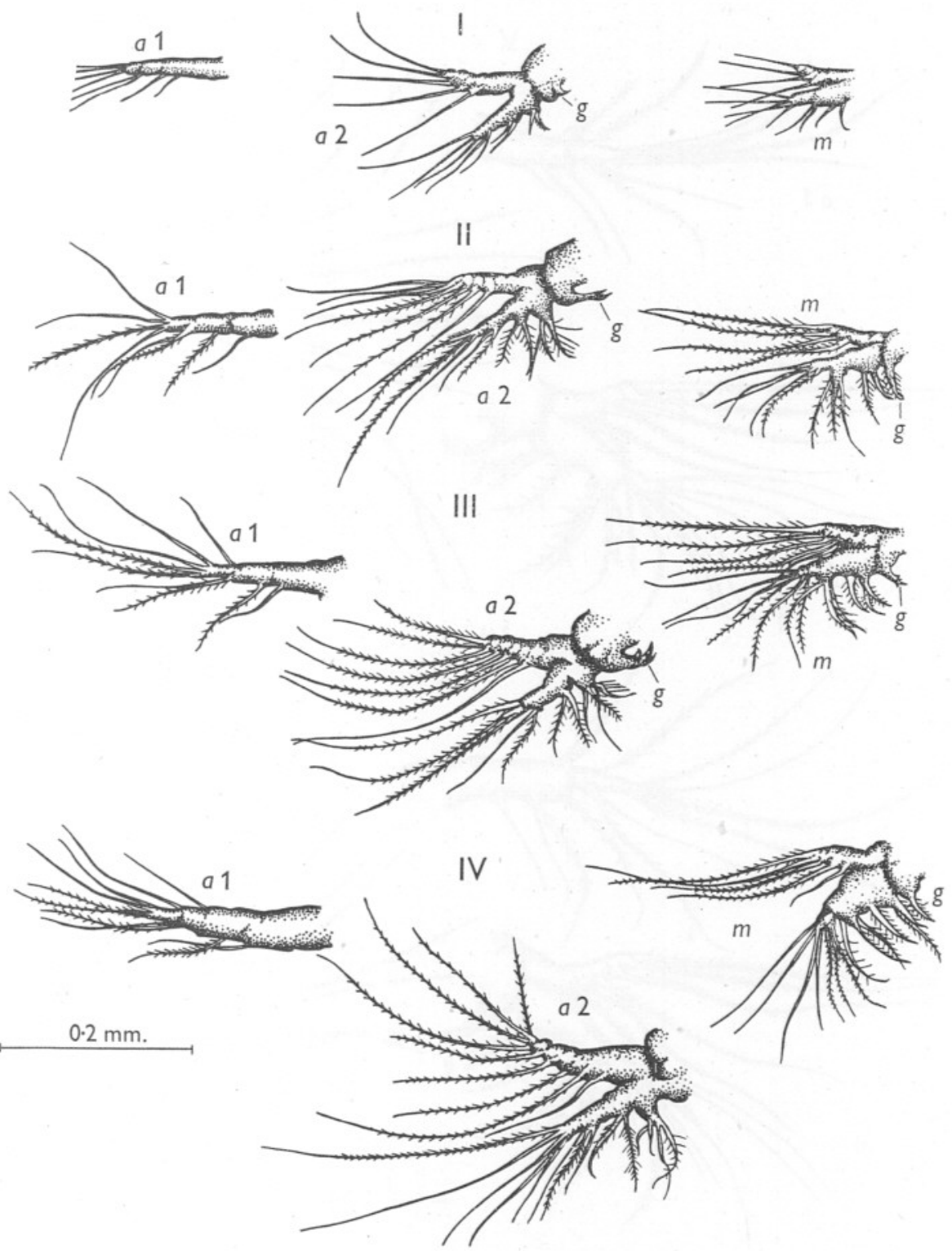

Fig. 5. Elminius modestus. The limbs of naupliar Stages I-IV; antenna I $(a \mathrm{I})$ on the left, antenna $2\left(a_{2}\right)$ in the centre; mandible $(m)$ on the right; $g$, gnathobase. 


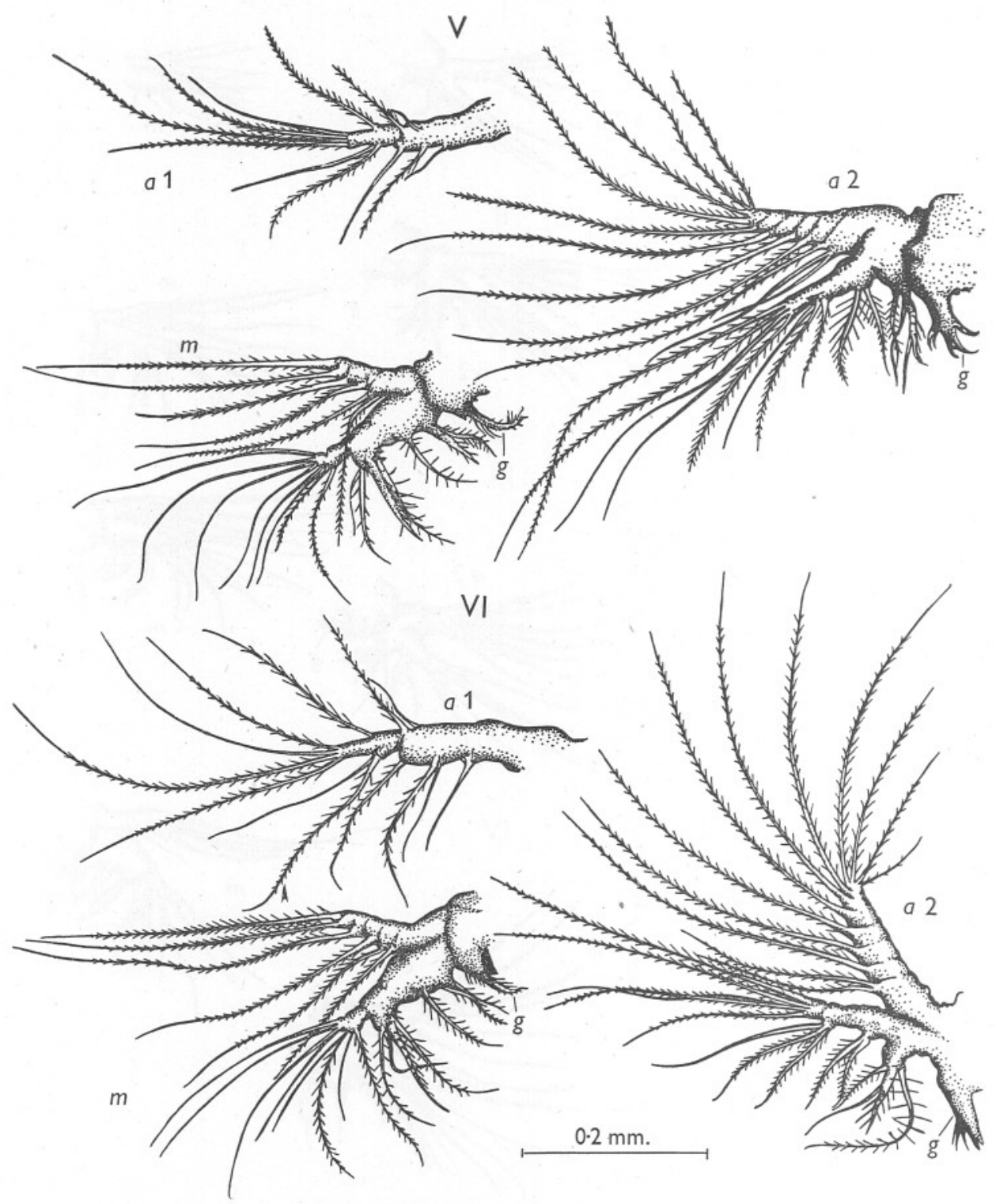

Fig. 6. Elminius modestus. The limbs of naupliar Stages V and VI; $a \mathrm{I}$, antenna $\mathrm{I} ; a 2$, antenna 2 ; $m$, mandible; $g$, gnathobase. 
a low-power binocular microscope. Herz (1933) had described the development of Balanus crenatus, but the work of Bassindale and Pyefinch suggests strongly that he was wrong in ascribing eight naupliar stages to these species. Pyefinch found that $B$. crenatus in the Clyde passed through only six naupliar stages, like every other species of barnacle so far described. We have not examined the larvae of these species, but it may be useful to draw attention to the points in which Elminius larvae differ from the published descriptions of them. The only species which was observed in our plankton samples from June onwards, besides Elminius, was Balanus improvisus. No adequate description of the larvae of this species is yet available in this country. The figures of Stages I and II given by Buchholz (Münter \& Buchholz, I870) and reproduced by Hoek (1909) are somewhat schematic and the limb setation is inaccurately reproduced. Figures of later stages by Filatowa (1902) and Tengstrand (I93I) are too small to be of value, and we were notable to consult the account of Lucks (I940), referred to by Thorson(I946) as figuring Stages IV and VI and the cyprid.

We have obtained Stage I nauplii from adult $B$. improvisus. They moulted overnight to give Stage II nauplii and we also observed this stage in the plankton of the River Crouch and the River Conway (North Wales). We examined one larger larva from the plankton which was not Elminius modestus and did not agree with the description of any other form. It had abdominal appendages clearly visible within the cuticle of the swollen abdomen, and it was probably the stage of Balanus improvisus immediately preceding the metanauplius, i.e. probably a Stage $\mathrm{V}$ nauplius.

The following appear to be the main points of comparison between the larvae of Elminius modestus and those of native barnacles.

\section{Size}

The particularly squat nauplii of Chthamalus are so much shorter and the bulky nauplii of Balanus balanoides so much larger than those of Elminius modestus that it is unnecessary to go further into the differences between these species in size and shape. Balanus crenatus larvae from the Clyde are also markedly larger than the corresponding stages of Elminius modestus, whilst Balanus perforatus and Verruca stroemia are slightly larger. The larvae of Elminius modestus and Balanus improvisus, however, are very similar in size.

\section{Shape}

The later stages of Verruca are unlikely to be confused with those of Elminius because Verruca, like Chthamalus, has a short rounded carapace and no carapace spines. A Stage II Verruca differs from that of Elminius in possessing a much longer abdominal process which reaches to the end of the caudal spine. A Stage III Verruca is considerably longer than any Elminius stage younger than Stage IV, and is quite unlike a Stage IV Elminius in having no posterior edge to its carapace. 
The larvae of Balanus improvisus, B. crenatus and B. perforatus resemble the corresponding stages of Elminius modestus fairly closely in general shape. A Stage II E. modestus can be distinguished, however, by its long caudal spine and short abdominal process (Fig. 3). In E. modestus of this stage the caudal spine is longer than the abdominal process by $0.06-0.10 \mathrm{~mm}$. In Balanus improvisus the caudal spine is longer by only $0.0 \mathrm{I}-0.05 \mathrm{~mm}$., and in B. crenatus the difference in length appears to be smaller still. Although the total length of the abdominal process in Stage II of Elminius modestus is comparatively small the prongs of the forked terminal portion (included in the total length) are of great relative length and comparatively great absolute length (0.05$0.06 \mathrm{~mm}$.). In Balanus improvisus they are only $0.03-0.04 \mathrm{~mm}$., and in all other British species of barnacle so far described they appear to be shorter still.

In $B$. perforatus, Stages II and III, the outline is unlike that of Elminius and of other native species of Balanus so far described, in that there is a distinct notch in the lateral margin on each side. This is shown in Groom's figures (I894) of Stages II and III, and Lochhead's figure (I936) of Stage II, all seen in ventral view. It appears to correspond to the posterior margin of the carapace.

In Elminius modestus the great length of the caudal spine in Stage II is foreshadowed by a slight elongation of this region in Stage I. Nauplii of the corresponding stages of Balanus improvisus, though similar in width to Elminius modestus, are shorter. Measurements of a few larvae of Balanus improvisus from the River Crouch and from the estuary of the River Conway, North Wales, were as follows:

$\begin{array}{lcc}\text { Greatest width } & \begin{array}{c}\text { Total length } \\ \text { (mm.) }\end{array} \\ \text { Stage I } & 0.13 & 0.20-0.21 \\ \text { Stage II } & 0.15-0.16 & 0.33-0.36\end{array}$

\section{Limb setation}

Bassindale, after giving the setation formulae for Stages I and II of B. crenatus and $B$. perforatus, remarked that 'a close comparison of these formulae with those for $B$. balanoides indicates the close similarity of the nauplii which are also similar in general shape and size'. This seems to imply that the similarity between the setation formulae of the early stages of these three species confirms that their taxonomic relationship is close. Such an interpretation is misleading, for the formulae which he gave for the same stages of Chthamalus and Verruca are also very similar to each other and to those given for Balanus.

It now appears that there is remarkable resemblance between the setation formulae of the earlier stages of all barnacles which have so far been studied. This is shown in Table IV. The formulae for Elminius modestus and Balanus improvisus were derived from specimens from the River Crouch, the remainder are taken from Bassindale (1936). It will be seen that the formula for Stage I nauplii of Elminius modestus is identical with that of Balanus improvisus, and 
with that given by Bassindale for B. crenatus. Otherwise there are small differences at both stages between Elminius modestus and the various species of Balanus, although these barnacles are all closely related, being included in the same family (Balanidae). On the other hand, the formulae for Stage II nauplii of Elminius modestus (Balanidae), Chthamalus stellatus (Chthamalidae) and Verruca stroemia (Verrucidae) are identical. Evidently the small differences and resemblances between the setation formulae of the early larvae of different species are of no systematic importance within these three families.

The formulae for the later stages of Elminius modestus (and of barnacles generally) are more distinctive, although that of Stage III nauplii of Elminius is identical, and that of Stage IV nauplii almost identical, with those given for the corresponding stages of Chthamalus stellatus (another point of resemblance which extends across an accepted taxonomic division).

\section{Table IV. The Setation Formulae for the First Two Naupliar Stages of Seven Common Species of Barnacle}

\begin{tabular}{|c|c|c|c|c|}
\hline Species & Stage & Antennule & Antenna & Mandible \\
\hline Balanus balanoides & I & $\begin{array}{l}\text { O.4.2.I.I } \\
\text { O.4.2.I.I }\end{array}$ & $\begin{array}{l}0.1 \cdot 4-0.3 \cdot 2 \cdot 2 \cdot 2 . G \\
0.1 \cdot 6-0.3 \cdot 2 \cdot 2 \cdot 2 . G\end{array}$ & $\begin{array}{l}0.1 \cdot 3-0.3 \cdot 2 \cdot 3 \cdot 2 . G \\
0.1 \cdot 3-0.3 \cdot 3 \cdot 3 \cdot 2 . G\end{array}$ \\
\hline B. perforatus & I & $\begin{array}{l}\text { O.4.I.I.I; } \\
\text { O.4.2.I.I; }\end{array}$ & $\begin{array}{l}0.1 \cdot 4-0.3 \cdot 2 \cdot 2 \cdot 2 \cdot G \\
0.2 \cdot 5-0.3 \cdot 2 \cdot 2 \cdot 3 \cdot G\end{array}$ & $\begin{array}{l}0 . I \cdot 3-0.2 \cdot I \cdot 2 \cdot 2 \cdot G \\
0.1 \cdot 3-0.3 \cdot 2 \cdot 3 \cdot 2 \cdot G\end{array}$ \\
\hline B. crenatus & $\begin{array}{l}\text { I } \\
\text { II }\end{array}$ & $\begin{array}{l}\text { O.4.2.I.I } \\
\text { O.4.2.I.I }\end{array}$ & $\begin{array}{l}0.1 \cdot 4-0.3 \cdot 2 \cdot 2 \cdot 2 \cdot G \\
0.1 \cdot 6-0.3 \cdot 2 \cdot 2 \cdot 2 \cdot G\end{array}$ & $\begin{array}{l}0.1 \cdot 3-0.3 \cdot 2 \cdot 2 \cdot 2 \cdot G \\
0.1 \cdot 3-0 \cdot 3 \cdot 2 \cdot 3 \cdot 3 \cdot G\end{array}$ \\
\hline B. improvisus & $\begin{array}{l}\text { I } \\
\text { II }\end{array}$ & $\begin{array}{l}\text { O.4.2.I.I; } \\
\text { O.4.2.I.I }\end{array}$ & $\begin{array}{l}0.1 \cdot 4-0.3 \cdot 2 \cdot 2 \cdot 2 . G \\
0.1 \cdot 6-0.3 \cdot 2 \cdot 2 \cdot 3 \cdot G\end{array}$ & $\begin{array}{l}0.1 \cdot 3-0.3 \cdot 2 \cdot 2 \cdot 2 \cdot G \\
0.1 \cdot 4-0.3 \cdot 2 \cdot 3 \cdot 2 \cdot G\end{array}$ \\
\hline Elminius modestus & I & $\begin{array}{l}\text { O.4.2.I.I } \\
\text { O.4.2.I.I }\end{array}$ & $\begin{array}{l}0.1 \cdot 4-0.3 \cdot 2 \cdot 2 \cdot 2 . G \\
0.1 \cdot 6-0.3 \cdot 2 \cdot 2 \cdot 3 \cdot G\end{array}$ & $\begin{array}{l}0.1 \cdot 3-0.3 \cdot 2 \cdot 2 \cdot 2 . G \\
0.1 \cdot 3-0.3 \cdot 2 \cdot 3 \cdot 2 . G\end{array}$ \\
\hline Chthamalus stellatus & I & $\begin{array}{l}\text { O.4.I.I.I; } \\
\text { O.4.2.I.I; }\end{array}$ & $\begin{array}{l}0.1 \cdot 4-0.3 \cdot 2 \cdot 2 \cdot 2 \cdot G \\
0.1 \cdot 6-0.3 \cdot 2 \cdot 2 \cdot 3 \cdot G\end{array}$ & $\begin{array}{l}0.1 \cdot 3-0.3 \cdot 2 \cdot 2 \cdot 2 . G \\
0.1 \cdot 3-0.3 \cdot 2 \cdot 3 \cdot 2 . G\end{array}$ \\
\hline Verruca stroemia & $\begin{array}{l}\text { I } \\
\text { II }\end{array}$ & $\begin{array}{l}\text { O.4.2.I.I } \\
\text { O.4.2.I.I; }\end{array}$ & $\begin{array}{l}0.1 \cdot 4-0.3 \cdot 2 \cdot 2 \cdot 3 \cdot G ; \\
0.1 \cdot 6-0.3 \cdot 2 \cdot 2 \cdot 3 \cdot G ;\end{array}$ & $\begin{array}{l}0.1 \cdot 3-0.3 \cdot 2 \cdot 2 \cdot 2 \cdot G \\
0.1 \cdot 3-0.3 \cdot 2 \cdot 3 \cdot 2 \cdot G\end{array}$ \\
\hline
\end{tabular}

Because of this close resemblance between species and because the study of the limb setation of barnacle nauplii is at present incomplete, Bassindale's formula can safely be used only for confirming an identification made on other grounds, and for distinguishing between the different stages of a given species.

\section{Labrum}

In Ch. stellatus, and in Verruca stroemia, the labrum is a single tongue-shaped lobe with a rounded posterior end. In Balanus, in all stages except the earliest, the labrum is more or less square posteriorly. The labrum figured by Bassindale for Stage II nauplii of $B$. balanoides has three lobes, but the median lobe does not extend posteriorly beyond the lateral lobes so it does not interrupt the square shape. In his figure for Stage $\mathrm{V}$ nauplii of this species, no median lobe is shown. Stages I and II nauplii of B. improvisus also have a trilobed labrum, with a median lobe which does not extend posteriorly beyond the lateral lobes. 
The single large nauplius which we observed in the plankton and which was probably a Stage V of $B$. improvisus had a square labrum with no obvious median lobe. In all stages of $B$. crenatus (Herz, I933) and in all stages, except the first, of $B$. perforatus (Groom, I894) the labrum is trilobed, but the median lobe extends posteriorly only slightly beyond the lateral lobes.

In all naupliar stages of Elminius modestus the labrum is obviously trilobed with a long median lobe which extends posteriorly much farther than the lateral lobes. This character clearly marks out $E$. modestus larvae from those of all species so far described, but in using it to distinguish between $E$. modestus and Balanus improvisus (two species of which the nauplii are particularly liable to be confused), two pitfalls must be avoided. First, in Stages I and II of $B$. improvisus, although the median lobe of the labrum does not project posteriorly, it projects prominently in a ventral direction. It appears very prominently, therefore, in specimens of $B$. improvisus which are standing on their heads in a dish of plankton and which are being viewed posteriorly. Secondly, in many preserved specimens of Elminius modestus, the labrum projects from the body at an obtuse angle. The median lobe is then foreshortened in ventral view and the labrum may appear square. It follows that when using the form of the labrum to distinguish between these two species, each specimen should be viewed from the ventral direction. If the labrum is markedly trilobed, E. modestus is indicated. If it appears square, the specimen should be viewed under a supported cover-slip to ensure that the labrum is lying more or less flat. If it still appears square, Balanus improvisus is indicated.

\section{The cyprid}

The cyprid of Elminius modestus is colourless and of glassy transparency. Those from the River Crouch were $0.54-0.56 \mathrm{~mm}$. long. This is larger than the size which Bassindale gave for the cyprid of Chthamalus stellatus. It resembles in size that of Verruca stroemia, but differs in shape (see Fig. 4b) from the figure given by Pyefinch for this species, which showed a straight postero-dorsal margin and a pointed posterior end. It is much smaller than that of Balanus balanoides and distinctly smaller than that of B. crenatus in British waters and of $B$. perforatus. It resembles in size that of $B$. improvisus. Tengstrand (193I) gave the length of this cyprid as $0.6 \mathrm{~mm}$., in Swedish waters. A cyprid from the River Crouch, which was probably this species, was $0.53 \mathrm{~mm}$. long. This specimen was quite unlike a cyprid of Elminius modestus in being opaque and in having a blunter posterior end.

The later nauplii of Elminius thus resemble those of Balanus and differ from those of Chthamalus and Verruca in possessing a trilobed labrum and a fairly long carapace tapering posteriorly and bearing on its posterior margin a pair of carapace spines. They do not differ from those of Balanus in any important 
respect. Darwin (1854) suggested a close affinity between Elminius, Tetraclita and Balanus. He wrote that Elminius 'can be distinguished from Tetraclita only by the four compartments not being porose and by the basis being always membranous', and that Tetraclita 'is closely allied to Balanus; I can point out no difference in the animal's body, nor any constant difference in the opercular valves'.

The development of Elminius tends to confirm that this genus is closely related to Balanus.

\section{SUMMARY}

Nauplii of the first two stages were obtained from adult Elminius modestus and larvae of all stages, except the smallest, were obtained from the plankton over Essex oyster beds.

Over 200 nauplii of all sizes were measured. Their size distribution, plotted graphically, showed six peaks corresponding to six naupliar stages. The later stages were much more variable in size than the earlier stages.

The size limits and characteristics of each naupliar stage are given. Briefly, Stage I has the fronto-lateral horns pointing backwards. Stage II has the caudal spine much longer than the abdominal process. Stage III has the abdominal process about as long as the caudal spine, but has no carapace fold posteriorly. Stage IV has a carapace fold but no sign of the abdominal appendages. Stage V has the rudiments of these appendages showing indistinctly within the abdomen. In Stage VI the abdominal appendages are prominent.

The limb setation of each stage is figured and described according to Bassindale's formula. The taxonomic value of this formula is limited, since there is a remarkable resemblance between the formulae for the early nauplii of all species so far studied.

The larvae are compared with those of other barnacles of which the development has been described. In general, they resemble those of Balanus, but they are much smaller than those of $B$. balanoides and distinctly smaller than those of the corresponding stages of $B$. crenatus in the Clyde and B. perforatus in the English Channel. They are most likely to be confused with those of $B$. improvisus, which they resemble in size. The shape of the labrum is the most distinctive feature of $E$. modestus nauplii. It is trilobed, with the median lobe extending posteriorly much farther than the lateral lobes. 


\section{REFERENCES}

Bassindale, R., I936. The developmental stages of three English barnacles, Balanus balanoides (Linn.), Chthamalus stellatus (Poli) and Verruca stroemia (O. F. Müller). Proc. Zool. Soc. Lond., I936, pp. 57-74.

BISHOP, M. W. H., I947. Establishment of an immigrant barnacle in British coastal waters. Nature, Vol. CLIX, p. 501.

Crisp, D. J. \& ChIPPERFIELd, P. N. J., I948. Occurrence of Elminius modestus Darwin in British waters. Nature, Vol. CLXI, p. 64.

Darwin, C., I854. A monograph of the Sub-class Cirripedia. II. The Balanidae, the Verrucidae. London: Ray Society.

Filatowa, E., I902. Quelques remarques à propos du développement post-embryonnaire et l'anatomie de B. improvisus. Zool. Anz., Bd. xxv, pp. 379-85.

Groom, T. T., I894. The life-history of the rock barnacle (Balanus). Fournal of Marine Zoology and Microscopy, Vol. I, pp. 8I-6.

Herz, L. E., I933. The morphology of the later stages of Balanus crenatus Brugière, Biol. Bull. Woods Hole, Vol. LxIv, pp. 432-42.

Hoek, P. P. C., I909. Die Cirripedien des nordischen Planktons. Nordisches Plankton, Bd. IV, No. 8, pp. 265-33I.

KNIGHT-JoNES, E. W., 1948. Elminius modestus: another imported pest of east coast oyster beds. Nature, Vol. CLXI, p. 201.

LOCHHEAD, J. H., 1936. On the feeding mechanism of the nauplius of Balanus perforatus Brugière. Proc. Linn. Soc. (Zool.), Vol. xxxix, pp. 429-42.

Lucks, R., 1940. Crustaceen und Rotatorien aus den Brackgewässern der Danziger Umgebung. Bericht des Westpreussischen Botanisch-Zoologischen Vereins, Vol. LXII, pp. I-39. Danzig.

MÜNTER, J. \& BUchHolz, R., I870. Über Balanus improvisus Darwin var. gryphicus Münter. Mitth. naturwiss. Verein v. Neu-Vorpommern u. Rügen, Vol. I, pp. I-40.

Pyefinch, K. A., I948. Methods of identification of the larvae of Balanus balanoides (L.), B. crenatus Brug. and Verruca stroemia (O. F. Müller). Fourn. Mar. Biol. Assoc., Vol. xxviI, pp. 45I-63.

Tengstrand, G., I93I. Balanus improvisus, något om dess förekomst i Göta älvs mynning. Fauna och Flora, Vol. xxvI, pp. I08-I2. Stockholm.

Thorson, G., 1946. Reproduction and larval development of Danish marine bottom invertebrates, with special reference to the planktonic larvae in the Sound (Øresund). Medd. Komm. Danmarks Fisk. Havund. Kobenhavn, Ser. Plankton, Bd. 4, No. I, 523 pp. 